\title{
VAV3 wt Allele
}

National Cancer Institute

\section{Source}

National Cancer Institute. VAV3 wt Allele. NCI Thesaurus. Code C52964.

Human VAV3 wild type allele is located in the vicinity of 1p13.3 and is approximately 394

$\mathrm{kb}$ in leng th. This allele, which encodes guanine nucleotide exchange factor VAV3 protein, plays a role in the mediation of actin remodeling. 